\title{
Uji Farmakologis Ekstrak Kental Daun Meniran(Phyllanthus niruri Linn) Untuk Membantu Penyembuhan Luka Sayat Pada Tikus Putih Jantan (Rattus norvegicus strain Sprague-Dawley).
}

\author{
Herson Cahaya Himawan, M.Si ${ }^{1}$, Drs. Pramono Apt ${ }^{2}$. Dwi Ayu Resti ${ }^{3}$ \\ 1. Program Studi Farmasi Sekolah Tinggi Teknologi Industri dan Farmasi Bogor \\ 2. Program Studi Farmasi Sekolah Tinggi Teknologi Industri dan Farmasi Bogor \\ 3. Mahasiswa Program Studi S1 Farmasi Sekolah Tinggi Teknologi Industri dan Farmasi Bogor \\ Korespondensi: hersonindonesia2011@gmail.com
}

\begin{abstract}
ABSTRAK
Masyarakat sering menggunakan tanaman obat sebagai alternatif untuk penyembuhan yaitu luka. Luka sering dialami oleh tubuh manusia baik yang disengaja maupun yang tidak disengaja. Luka sayat adalah luka yang disebabkan karena sayatan dari benda tajam, kayu dan lain sebagainya. Salah satu tumbuhan yang sering digunakan sebagai terapi obat tradisional adalah daun meniran yang dapat membantu penyembuhan luka. Penelitian ini bertujuan untuk mengetahui efek ekstrak kental daun meniran (Phyllanthus niruri Linn) dalam mempercepat waktu penyembuhan luka sayat pada tikus putih jantan galur Sprague-Dawley. Ekstrak kental daun meniran diperoleh dari proses infusa dengan pelarut air pada suhu dibawah $60^{\circ} \mathrm{C}$ selama 15 menit. Pengujian ini dibuat 6 kelompok dengan kontrol negatif (luka dibiarkan), kontrol positif (diberi betadine) dan diberi ekstrak kental daun meniran konsentrasi 25\%, 50\%, 75\% dan 100\%. Ekstrak kental daun meniran diberikan secara topikal dalam empat tingkatan konsentrasi yaitu 25\%, 50\%, 75\% dan 100\%, Ekstrak dioleskan menggunakan kassa steril dengan luka sayat sepanjang $2 \mathrm{~cm}$ dan kedalaman $0,2 \mathrm{~cm}$ pada punggung tikus. Hasil penelitian menunjukkan bahwa dari tiap perlakuan konsentrasi mempunyai kemampuan untuk menyembuhkan luka sayat, tetapi mempunyai nilai yang berbeda. Kesimpulan dari penelitian ini adalah ekstrak kental daun meniran yang paling cepat untuk penyembuhan luka sayat pada tikus putih jantan galur Sprague- Dawley adalah konsentrasi $100 \%$ dan $75 \%$.
\end{abstract}

Kata Kunci: Ekstrak kental daun meniran, luka sayat, penyembuhan luka,Phyllanthusniruri Linn. 


\section{ABSTRACT}

People often use medicinal plants as an alternative to healing the wound. Injuries are often experienced by the human body either intentionally or unintentionally. The cut is a wound caused by an incision of a sharp object, wood and so on. One of the herbs that is often used as a traditional drug therapy is a meniran leaf that can help wound healing. The aim of this research is to know the effect of thick leaf extract of meniran (Phyllanthus niruri Linn) in accelerating the healing time of the wound on Sprague-Dawley male white rat. Gravy leaf extract was obtained from infusa process with water solvent at temperature below $60^{\circ} \mathrm{C}$ for 15 minutes. This test was made by 6 groups with negative control (wound left), positive control (given betadine) and given the thickness of leaves leaves concentrate $25 \%, 50 \%, 75 \%$ and $100 \%$. Meniran leaf-thick extract wastopicallyadministered in four concentrations of $25 \%, 50 \%, 75 \%$ and $100 \%$, extracted with sterile gauze with $2 \mathrm{~cm}$ deep cuts and $0.2 \mathrm{~cm}$ depth on the lower rats. The results showed that from each treatment the concentration has the ability to heal the wound, but has different values. The conclusions of this study were the fastest meniran leaf extracts for healing wounds in Sprague-Dawley Sprague-white male rats were concentrations of $100 \%$ and $75 \%$.

\section{Keywords: Meniran leaf thick extract, wound Incision, wound healing,Phyllanthus niruri Linn.}

\section{PENDAHULUAN}

Keanekaragaman hayati yang ada di bumi ini tidak hanya digunakan sebagai bahan pangan ataupun untuk dinikmati keindahannya saja, tetapi juga bermanfaat sebagai bahan untuk mengobati berbagai penyakit. Tumbuhan yang ada, terutama yang tumbuh di Indonesia dikenal sebagai bahan yang ampuh untuk obat dan digunakan sebagai bahan baku industri obat di Indonesia selain juga sebagai obat- obatan tradisional, tanaman yang berguna sebagai obat dapat juga kita temui sehari-hari. Tumbuhan obat dapat diartikan sebagai tumbuhan yang mempunyai kemampuan menyembuhkan penyakit [1]

Penyakit secara medis umumnya dapat diatasi dengan terapi obat-obat kimia, tetapi dapat pula diobati dengan obat tradisional. Usaha pengobatan melalui penggunaan tumbuhan obat sangat perlu dilakukan oleh masyarakat, sehingga tumbuhan obat dapat diramu menjadi obat tradisional yang dapat dimanfaatkan untuk menyembuhkan penyakit bagi masyarakat. Manfaat dan kegunaan obat tradisional sangat banyak sekali jika masyarakat bisa meramu dan menggunakan jenis-jenis tanaman yang berkhasiat sebagai obat tradisional. [2]).

Masyarakat sering menggunakan tanaman obat sebagai alternatif untuk penyembuhan yaitu luka. Luka sering dialami oleh tubuh manusia baik yang disengaja maupun yang tidak disengaja, luka yang tidak ditangani dengan baik dapat mengakibatkan infeksi, sehingga menyebabkan proses penyembuhan luka menjadi terganggu. Luka sayat adalah luka yang disebabkan karena sayatan dari benda tajam, kayu dan lain sebagainya[3] . Di pedesaan terutama daerah-daerah yang jauh dari apotek, dapat menggunakan bahan baku alami yang berasal dari tumbuhan untuk mengatasi berbagai penyakit, salah satu tumbuhan yang sering digunakan sebagai terapi obat tradisional adalah daun meniran yang membantu penyembuhan luka, salah satu cara yang biasa digunakan adalah daun meniran yang ditumbuk dan direbus dengan air, selanjutnya air rebusannya digunakan untuk mandi. Daun meniran ini merupakan tanaman obat dan dapat dijadikan sebagai obat tradisional yang memiliki banyak manfaat kesehatan terutama dalam penyembuhan berbagai penyakit dalam maupun luar [4].

Kandungan utama daun meniran adalah flavonoid, saponin, dan polifenol. Flavonoid terdapat dalam tumbuhan sebagai campuran, jarang sekali dijumpai hanya flavonoid tunggal dalam jaringan tumbuhan [5]

Daun meniran (Phyllanthus niruri Linn) dapat digunakan sebagai obat yang mampu memperbaiki sistem imun, rasanya pahit, baunya aromatik, sifatnya menyejukkan, dan seluruh bagian tanaman dapat digunakan sebagai obat, juga mengandung khasiat obat yang berguna bagi kita, dan zat-zat yang terkandung dalam daun meniran banyak sekali, yang mempunyai kemampuan membunuh bakteri dan diketahui mempunyai efek sebagai antimikroba [5]

Pada kasus luka terbuka sering terjadi infeksi yang disebabkan masuknya kuman atau bakteri pada luka yang akan memperlambat proses pemulihan kulit. Keadaan akan lebih buruk bila tidak segera diberi antiseptik [6] .

\section{METODE PENELITIAN}

Bahan: Bahan-bahan yang digunakan pada penelitian ini antara lain: ekstrak kental daun meniran, betadine, aquadest, alkohol $70 \%, \mathrm{CHCl}_{3}, \mathrm{H}_{2} \mathrm{SO}_{4}$, pereaksi mayer, pereaksi bourchardat, pereaksi dragendorf, serbuk magnesium ( $\mathrm{Mg}$ ), $\mathrm{HCl}$ pekat, $\mathrm{FeCl}_{3}$.

Alat:Alat-alat yang digunakan pada penelitian ini antar lain: Timbangan digital (ACIS AD-300i), tabung reaksi (IWAKI сте33), labu Erlenmeyer (IWAKI CTE33),

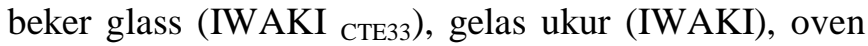
(memmert), hot plate (IKA RH basic), desikator, penggaris, kertas saring, pipet, corong, kandang tikus, kassa steril, kapas, gunting pencukur bulu, batang pengaduk, botol semprot, alumunium foil, $\mathrm{pH}$ meter, sarung tangan, masker, pinset, pisau bedah bisturi(BRAUN).

\section{Pengumpulan Bahan}

Bahan yang digunakan dalam penelitian ini adalah daun meniran segar yang diambil dari Balai Penelitian 
Tanaman Rempah dan Obat (BALITRO).

\section{Pembuatan Simplisia DaunMeniran}

Daun Meniran diambil pada pagi hari, dikumpulkan dan dibersihkan dari pengotor dengan air mengalir, ditiriskan diatas tampah yang dialasi kertas Koran. Selanjutnya ditimbang sebagai berat basah sebesar 2 $\mathrm{kg}$, kemudian dikeringkan dengan cara dianginanginkan didalam ruangan yang tidak terkena cahaya matahari langsung selama 1 - 2 hari, sampel yang telah kering dibersihkan.

\section{Penentuan Kadar Air}

Persiapan yang perlu dilakukan adalah cawan porselen yang akan digunakan terlebih dahulu dikeringkan dalam oven pada suhu $100^{\circ} \mathrm{C}$ selama

15 menit kemudian di dinginkan dalam desikator selama 10 menit. Selanjutnya cawan ditimbang dengan menggunakan neraca analitik. Sampel ditimbang sebanyak kurang lebih 3 gram kemudian dikeringkan dalam oven selama kurang lebih 6 jam. Setelah itu, di dinginkan dalam desikator kemudian ditimbang. Sampel kembali dikeringkan dalam oven selama 30 menit lalu ditimbang kembali. Perlakuan terakhir ini diulangi terus hingga diperoleh berat kering yang relatif konstan (berat dianggap konstan jika selisih berat sampel kering yang ditimbang $\geq 0,003$ gram). Rumus perhitungan kadar air, sebagai berikut .

Kadar air $(\%)=\frac{a-b}{a} \times 100 \%$

pemanasan $(\mathrm{g})$

$$
\mathrm{a}=\text { bobot sampel sebelum }
$$

$\mathrm{b}=$ bobot sampel setelah pemanasan $(\mathrm{g}$

\section{Pembuatan Ekstrak Daun Meniran}

Daun meniran yang sudah dikeringkan dan dihaluskan ditimbang dan diambil berat simplisia sebanyak $500 \mathrm{~g}$ direbus dengan $500 \mathrm{ml}$ air dengan

suhu $60^{\circ} \mathrm{C}$ selama 15 menit. Disaring dengan menggunakan kertas saring, setelah itu kentalkan menggunakan hot plate sampai didapatkan ekstrak kental daun meniran.Rendeman ekstrak total dihitung dengan membagi berat ekstrak yang dihasilkan dengan berat simplisia serbuk). Perhitungan rendeman ekstrak total dapat dilakukan berdasarkan persamaan berikut

$\%$ Rendemen $=\frac{\text { bobot ekstrak kental }}{\text { bobot serbuk }} \times 100 \%$

\section{Uji Fitokimia[7]}

UjiAlkaloid

Sejumlah sampel ditetesi dengan 5 tetes $\mathrm{NH}_{3}$ di tambah dengan $5 \mathrm{ml}$ kloroform dan disaring kedalam tabung reaksi. Filtrat dalam tabung reaksi dikocok dengan penambahan 10 tetes $\mathrm{H}_{2} \mathrm{SO}_{4} 2 \mathrm{M}$ kemudian lapisan asamnya dipindahkan kedalam tabung reaksi yang lain. Lapisan asam ini di teteskan pada plat tetes dibagi menjadi 3 bagian dan masing-masing ditambahkan perekasi Mayer, Bourchardat, dan Dragendorf. Hasil uji dinyatakan positif bila dengan pereaksi Mayer ditunjukan dengan adanya endapan putih atau kuning, pereaksi Bourchardat ditunjukan dengan adanya endapan coklat hitam, dan endapan merah hingga jingga dengan pereaksiDragendorf.

UjiFlavonoid

Sejumlah sampel ditambahkan beberapa $\mathrm{ml}$ air kemudian didihkan selama 5 menit lalu disaring. Sebanyak $5 \mathrm{ml}$ filtrat ditambahkan serbuk (Mg), $\mathrm{HCl}$ :Etanol (1:1) dan amil alkohol. Campuran dikocok kuat-kuat. Uji positif ditandai dengan munculnya warna merah, kuning atau jingga pada lapisan amilalkohol.

Uji Saponin

Sejumlah sampel ditambahkan dengan beberapa $\mathrm{ml}$ air kemudian didihkan selama 5 menit lalu disaring. Sebanyak $5 \mathrm{ml}$ filtrat dikocokdalam tabung reaksi tertutup selama 10 detik untuk dibiarkan selama 10 menit. Adanya saponin ditunjukan dengan terbentuknya buih stabil.

UjiTanin

Sejumlah sampel ditambahkan beberapa $\mathrm{ml}$ air dan didihkan selama 5 menit lalu disaring. Filtrat ditetesi $\mathrm{FeCl}_{3} 1 \%$. Uji positif ditandai dengan munculnya warna hitam kehijauan.

Uji Steroid danTriterpenoid

Sejumlah sampel dilarutkan dalam $2 \mathrm{ml}$ kloroform dalam tabung reaksi yang kering, lalu ditambahkan 10 tetes asetat anhidrat dan 3 tetes asam sulfat pekat. Reaksi positif ditunjukan dengan terbentuknya larutan bewarna merah untuk pertama kali lalu berubah menjadi warna biru atau hijau untuk steroid serta merah atau ungu untuktriterpenoid.

\section{Pembuatan Variasi Konsentrasi Ekstrak Kental DaunMeniran}

Dibuat masing-masing konsentrasi ekstrak kental daun meniran $20 \mathrm{ml}$

Konsentrasi25\% : Masukan $5 \mathrm{ml}$ ekstrak kental daun meniran dalam beker glass, kemudian ditambahkan air sampai $20 \mathrm{ml}$

Konsentrasi50\% : Masukan $10 \mathrm{ml}$ ekstrak kental daun meniran dalam beker glass, kemudian ditambahkan air sampai $20 \mathrm{ml}$

Konsentrasi75\% : Masukan $15 \mathrm{ml}$ ekstrak kental daun meniran dalam beker glass, kemudian ditambahkan air sampai $20 \mathrm{ml}$

Konsentrasi100\% : Masukan $20 \mathrm{ml}$ ekstrak kental daun meniran dalam beker glass

\section{HewanPercobaan}

Hewan yang digunakan pada penelitian ini adalah 24 tikus putih jantan galur Sprague-Dawley (Rattus norvegicus strain Sprague-Dawley) berat badan 150250 gram dan usia 2,5-3 bulan. Kenapa memakai tikus jantan? Karena hormon pada tikus jantan tidak dipengaruhi oleh hormon reproduksi, hal ini disebabkan adanya hormon esterogen pada tikus putih jantan relatif rendah di bandingkan dengan tikus putih betina.

\section{Pemberian Ekstrak Kental Daun Meniran}

KelompokI : Kontrol negatif, luka tikus dibiarkan

Kelompok II : Kontrol positif, diberi larutanbetadine 
Kelompok III : Diberi ekstrak kental konsentrasi25\%

Kelompok IV : Diberi ekstrak kental konsentrasi50\%

KelompokV : Diberi ekstrak kental konsentrasi75\%

KelompokVI : Diberi ekstrak kental konsentrasi $100 \%$

\section{Perlakuan dan Pengumpulan Data \\ Cara Pembuatan Luka}

Pembuatan luka dilakukan pada tikus putih dengan cara hewan uji dicukur bulunya di daerah puggung dan sekitarnya dibersihkan denganalkohol $70 \%$, tikus terlebih dahulu dimasukkan dalam toples yang berisi kloroform sampai pingsan (Hilang kesadaran). Selanjutnya diukur menggunakan penggaris dengan panjang $2 \mathrm{~cm}$, dan kedalaman $0,2 \mathrm{~cm}$, dilukai menggunakan pisau bedah bisturi. Tunggu 1 hari kemudian luka sayat tersebut diberi ekstrak daun meniran menggunakan kassa steril dengan berbagai konsentrasi $(25 \%, 50 \%, 75 \%, 100 \%)$.

Cara pemberian Ekstrak kental Daun meniran

Pemberian ekstrak kental daun meniran dilakukan 2 kali sehari menggunakan kassa steril yang diteteskan ekstrak kental daun meniran 2 - 3 tetes pada pagi dan sore hari selama 13 hari berturut-turut dimulai dari hari kedua tikus diberi luka sampai terlihat adanya proses penyembuhan luka. Pengamatan proses penyembuhan panjang luka dilakukan pada hari 0 sampai hari ke 13 setelah pembuatan luka. Penyimpanan ekstrak kental

\section{Uji Statistik}

Data Uji farmakologis ekstrak kental daun meniran yang diperoleh, diolah dengan menggunakan ANOVA satu arah yang diolah menggunakan software IBM SPSS Statistic ver.16, dengan taraf kepercayaan 95\% sehingga dapat diketahui apakah perbedaan yang diperoleh bermakna atau tidak dengan nilai signifikan (p 0,05). Jika terdapat perbedaan yang bermakna, maka dilanjutkan dengan uji Tukey HSD untuk membandingkan seluruh pasangan rata-rata perlakuan dan uji Duncan untuk interaksi antara perlakuan dan pelarut yang dilakukan secara manual menggunakan MicrosoftExcel.

Uji Normalitas: Bertujuan untuk melihat apakah data berdistribusi normal atautidak.

Jika, nilai Sig > 0,05: $\mathrm{H}_{0}$ Diterima, $\mathrm{H}_{1}$ Ditolak

Anova: Bertujuan untuk melihat apakah data mempunyai perbedaan nyata atautidak.

Jika, nilai Sig $<0,05: \mathrm{H}_{0}$ Ditolak, $\mathrm{H}_{1}$ Diterima daun meniran disimpan didalam lemaripendingin.

\section{HASIL DAN PEMBAHASAN}

\section{Pembuatan Simplisia Daunmeniran}

Daun meniran segar sebanyak $2 \mathrm{~kg}$ dikeringkan dengan cara diangin- anginkan 1 sampai 2 hari, dan menghasilkan 502,00 gram simplisia kering dan didapat hasil perhitungan susut pengeringan sebesar yang tertera pada lampiran 5. Secara organoleptik simplisia yang dihasilkan berwarna hijau kecoklatan dengan bau yang khas.

Tujuan pengeringan ialah untuk mengurangi kadar air serta menghentikan reaksi enzimatis yang terjadi pada sampel yang bisa mengurai lebih lanjut kandungan zat aktif, selain sampel menjadi lebih awet, pengurangan kadar air akan memudahkan pelarut menarik komponen bioaktif dalam sampel [7] .

Penggunaan metode pengeringan dengan cara dianginanginkan bertujuan meminimalisir rusaknya senyawa aktif yang tidak tahan pada temperatur tinggi, sehingga pengeringan sampel digunakan metode dengan temperatur yang rendah [8] 


\section{HASIL DAN PEMBAHASAN}

\section{Pembuatan Simplisia Daunmeniran}

Daun meniran segar sebanyak $2 \mathrm{~kg}$ dikeringkan dengan cara diangin- anginkan 1 sampai 2 hari, dan menghasilkan 502,00 gram simplisia kering dan didapat hasil perhitungan susut pengeringan sebesar yang tertera pada lampiran 5. Secara organoleptik simplisia yang dihasilkan berwarna hijau kecoklatan dengan bau yang khas.

Tujuan pengeringan ialah untuk mengurangi kadar air serta menghentikan reaksi enzimatis yang terjadi pada sampel yang bisa mengurai lebih lanjut kandungan zat aktif, selain sampel menjadi lebih awet, pengurangan kadar air akan memudahkan pelarut menarik komponen bioaktif dalam sampel [7] .

Penggunaan metode pengeringan dengan cara dianginanginkan bertujuan meminimalisir rusaknya senyawa aktif yang tidak tahan pada temperatur tinggi, sehingga pengeringan sampel digunakan metode dengan temperatur yang rendah [8]

\section{Penetapan Kadar Air}

Hasil pemeriksaan kadar air simplisia diperoleh sebesar 9,3\%. Simplisia dinilai cukup aman dalam penyimpanan bila mempunyai kadar air tidak lebih dari $10 \%$, karena jika kadar air melewati $10 \%$ kemungkinan
5

besar simplisia dapat dengan mudah ditumbuhi jamur.

\section{Ekstraksi DaunMeniran}

Perebusan terhadap 500,00 gram simplisia daun meniran yang dilakukan selama 15 menit dengan suhu $60^{\circ} \mathrm{C}$ dengan menggunakan pelarut air sebanyak

$500 \mathrm{ml}$, kemudian disaring menggunakan kertas saring dan didapatkan hasil 186,21 gram berwarna hijau kehitaman. Setelah direbus ekstrak dikentalkan menggunakan hotplate selama 15 menit, ekstrak kental yang diperoleh sebanyak 110,12 gram.

Besarnya rendeman ekstrak menunjukan banyaknya jumlah komponen senyawa aktif yang terekstrak selama proses perebusan. Rendeman yang diperoleh dari ekstraksi daun meniran adalah 22,02\%.

\section{SkriningFitokimia}

Uji Fitokimia dilakukan untuk mengetahui kandungan senyawa kimia yang terdapat dalam sampel. Uji fitokimia yang dilakukan merupakan jenis analisis kualitatif, yakni hanya mengidentifikasi keberadaan suatu senyawa tanpa menentukan kadarnya

Uji ini meliputi 4 uji yaitu Alkaloid, Flavonoid, Saponin dan Tanin yang dilakukan berdasarkan visualisasi warna.

Tabel 1. Hasil Uji Skrining Fitokimia Ekstrak Daun Meniran

\begin{tabular}{|l|c|l|}
\hline Pengujian & Hasil Pengamatan & Keterangan \\
\hline Alkaloid & - & $\begin{array}{l}\text { Tidak terjadi endapan Tidak } \\
\text { terjadi endapan Tidak terjadi } \\
\text { endapan }\end{array}$ \\
$\begin{array}{l}\text { Mayer } \\
\text { 3. Pereaksi Dragendorf }\end{array}$ & - & \\
\hline Flavonoid & + & Merah \\
\hline Saponin & + & Busa stabil \\
\hline Tannin & + & Hijau kehitaman \\
\hline
\end{tabular}

Keterangan: + (positif mengandung), - (negatif tidak mengandung)

Senyawa Flavonoid bersifat sebagai anti inflamasi, anti alergi, mencegah proses oksidasi, dan anti oksidan serta berbagai fungsi lainnya. Flavonoid mencegah oksidasi dan menghambat zat yang bersifat racun yang bisa timbul pada luka. Proses penyembuhan luka yang ditandai dengan penutupan luka oleh eksudat dan pengurangan panjang luka dari setiap ekstrak kental berbeda [9]

Senyawa Saponin memiliki kemampuan sebagai pembersih dan antiseptik yang berfungsi membunuh atau mencegah pertumbuhan mikroorganisme pada luka sehingga luka tidak mengalami infeksi yang berat [10] Senyawa Tanin berfungsi sebagai adstringen atau mengkerutkan jaringan yang dapat menyebabkan penciutan pori-pori kulit, memperkeras kulit, menghentikan eksudat dan pendarahan yang ringan sehingga mampu menutupi luka dan mencegah pendarahan yang biasa timbul pada luka [11].

Hasil Pembuatan Ekstrak Kental DaunMeniran Ekstrak kental yang dibuat memiliki bentuk kental, bau khas, warna hampir semua sama hijau kehitaman dengan konsentrasi 25\%, 50\%, 75\%, 100\%. Ekstrak kental daun meniran yang dibuat didapatkan hasil seperti yang tertera pada gambar 1. dibawahini: 


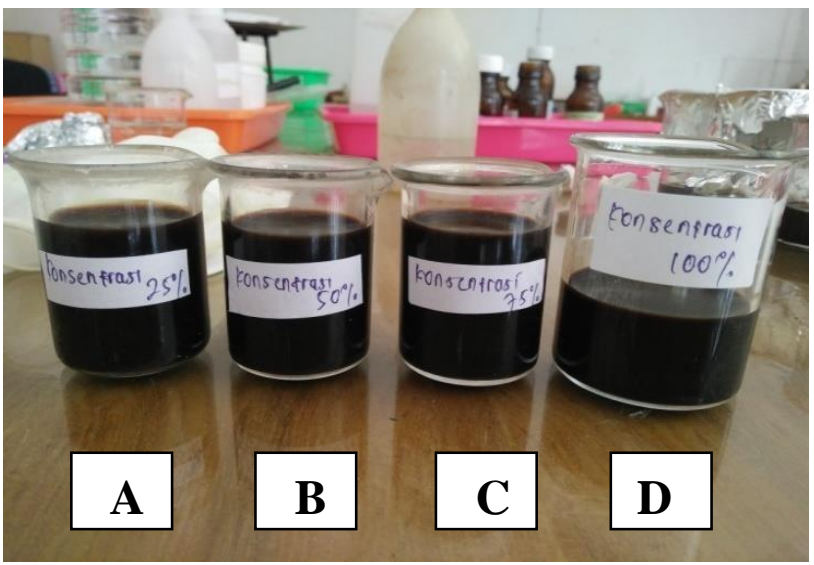

Gambar 1. Sediaan Ekstrak Kental Daun Meniran Ekstrak kental Daun meniran konsentrasi25\% Ekstrak kental Daun meniran konsentrasi50\% Ekstrak kental Daun meniran konsentrasi75\% Ekstrak kental Daun meniran konsentrasi100\% 
Tabel 2. Hasil Uji pH

\begin{tabular}{|l|l|}
\hline Jenis Ekstrak Kental & pH \\
\hline Ekstrak kental daun meniran konsentrasi 25\% v/v & 7.04 \\
\hline Ekstrak kental daun meniran konsentrasi 50\% ${ }^{\mathrm{v}} / \mathrm{v}$ & 7.06 \\
\hline Ekstrak kental daun meniran konsentrasi $75 \%$ v $/ \mathrm{v}$ & 7.05 \\
\hline Ekstrak kental daun meniran konsentrasi $100 \%$ v $/ \mathrm{v}$ & 7.06 \\
\hline
\end{tabular}

Gambar 2. Grafik Rerata Panjang Luka Sayat

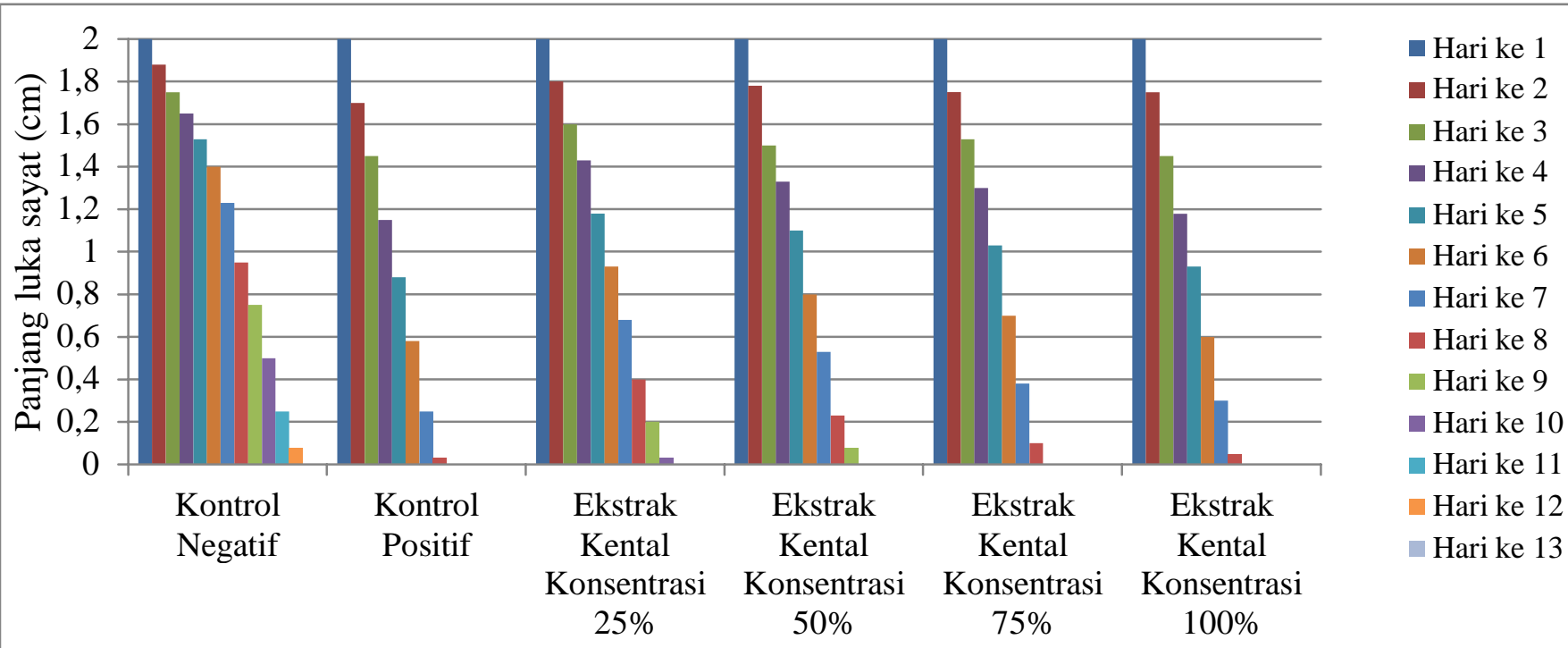

Kelompok Perlakuan

Proses penyembuhan luka terdini dari 3 fase yaitu fase Inflamasi, fase Poliferasi, dan fase Maturasi. Fase inflamasi terjadi pada hari ke-0 dibuat luka yang ditandai dengan adanya pembekakan yang disebabkan oleh prostal, fase poliferasi terjadi pada hari ke-1 sampai hari ke-7 ditandai dengan adanya pembentukan eksudat dan fibrolas yang terlihat seperti kerak pada bagian atas luka, dan fase maturasi terjadi pada hari ke8 sampai hari ke 13 yang ditandai dengan terbentuknya jaringan kulit baru.

Hasil pengukuran panjang luka terhadap proses penyembuhan luka terbuka pada tikus putih jantan dengan berat 150-250 g selama 13 hari. Pengukuran panjang luka untuk semua kelompok perlakuan pada hari ke-2 sampai hari ke-13 mengalami perubahan. Pada hari ke-0 untuk semua kelompok perlakuan masih terbuka dan belum terlihat adanya perubahan karena belum diberi perlakuan, pada hari ke-1 untuk semua kelompok perlakuan terlihat timbulnya seperti kerak kering dan merah dibagian luka karena belum diberi perlakuan, untuk hari ke-2 perubahan sedikit terlihat sedangkan pada hari ke-3 sampai hari ke-6 tepi luka untuk semua perlakuan mulai menyempit, sedangkan penyembuhan yang signifikan terlihat pada hari ke-7 dan hari ke-9 dimana luka tertutup sempurna yaitu pada kontrol positif (betadine), ekstrak kental daun meniran dengan konsentrasi $100 \%$ dan $75 \%$, sedangkan ekstrak kental daun meniran pada konsentrasi $50 \%$ tertutup sempurna pada hari ke-10 dan ekstrak 25\% tertutup pada hari ke-11. Artinya didalam ekstrak kental daun meniran mengandung zat aktif yang mampu meningkatkan aliran darah ke daerah luka, sedangkan perubahan yang paling rendah yaitu terdapat pada kontrol negatif tertutup pada hari ke-13 karena tanpa adanya perlakuan, tetapi kelompok ini juga mengalami penyembuhan luka sedikit lebih lama, ditandai dengan mengecilnya panjang luka pada tikus putih jantan. Ekstrak kental daun meniran yang memberikan efek penyembuhan paling besar adalah ekstrak kental daun meniran dengan konsentrasi $100 \%$ dan $75 \%$ dibandingkan dengan konsentrasi $50 \%$ dan 25\%. Hal ini disebabkan karena semakin besar konsentrasi ekstrak daun meniran, maka semakin cepat waktu yang diperlukan untuk penyembuhan luka.

\section{Simpulan}

Berdasarkan hasil penelitian yang telah dilaksanakan dapat disimpulkan bahwa:

Kandungan senyawa dalam ekstrak kental daun meniran yaitu flavonoid, saponin, tanin dansteroid.

Hasil uji penyembuhan luka sayat ekstrak kental daun meniran dengan konsentrasi 25\%, 50\%, 75\% dan 100\% dapat mempercepat proses penyembuhan luka, yang merupakan ekstrak kental paling cepat menyembuhkan 
luka yaitu konsentrasi100\%.

Konsentrasi $100 \%$ dengan kontrol positif mempunyai nilai sama terhadap penyembuhan luka sayat pada tikus putih jantan.

\section{Saran}

Perlu dibuat formulasi, supaya sediaan bisa lebih baik dari segi penyimpanan danpenggunaan.

\section{DAFTAR PUSTAKA}

[1] Maharani Putri, 2011. Tanaman Obat yang Harus Ada di Pekarangan Rumah Kita. Yogyakarta: Sinar Ilmu, Hal

[2] Kumala L.U.R. 2006. Pemanfaatan Obat Tradisional Dengan Pertimbangan Manfaat dan keamanannya. Majalah Ilmu Kefarmasian. Jakarta, Vol. 3 no. 1.

[3] Perdanakusuma, D. S. 2007. Anatomi Fisiologi Kulit dan Penyembuhan Luka. Disampaikan dalam: "From Caring to Curing, Pause Before You Use Gauze". Hotel JW Marriot Hotel Surabaya, 5 september 2007

[4] Kartasapoetra, G. 1992. Budidaya Tanaman Berkhasit Obat. Rineka Cipta.

Jakarta. $135 \mathrm{hlm}$.

[5] Sudibyo, M., 1998. Alam Sumber Kesehatan: Manfaat dan Kegunaan Daun Meniran, Jakarta: Balai Pustaka. Hal 325-326.

[6] Nagori, B.D and Solanki, R. 2011.Role of medical plants in woundhealing.

Research, journal of medical plant 5: 392-405.

[7]Harborne, J.B. 1996. Metode Fitokimia, Penuntun Cara Modern Menganalisis Tumbuhan. (Diterjemahkan oleh: K. Padmawinata dan i.Soediro).Bandung

: Penerbit Institut Teknologi Bandung, Hal 71-77.

[8]Robinson, T., 1995. Kandungan Organik Tumbuhan Tinggi. Edisi ke-6 Diterjemahkan oleh Kosasih Padmawinata: The organic constituents of higher plants $6^{\text {th }}(1991)$. Bandung: Institut Teknologi Bandung. Hal 191- 216.

[9] Hermani dan Nurdjanah, R. 2009. Aspek Pengeringan Dalam Mempertahankan Kandungan Metabolit Sekunder Pada Tanaman Obat. Jurnal Perkembangan Teknologi TRO 21 (2). Bogor: Balai Besar Penelitian dan Pengembangan PascapanenPertanian.

[9] Lutfiana, 2013. Uji Aktifitas Antiinflamasi Ekstrak Daun Kelor (Moringa oleifera Lam.) dengan Metode Stabilisasi Membran Sel Darah Merah Secara In Vitro, UIN Syarif Hidayatullah: Jakarta

[10] Robinson, T., 1995. Kandungan Organik
Tumbuhan Tinggi. Edisi ke-6 Diterjemahkan oleh Kosasih Padmawinata: The organic constituents of higher plants $6^{\text {th }}(1991)$. Bandung: Institut Teknologi Bandung. Hal 191- 216

[11] Suprapto AK. 2012. Efek Salep Ekstrak Metanol dan Salep Serbuk Daun Sosor Bebek (Kalanchoe pinnata (Lamk)). terhadap Penyembuhan Luka Sayat Pada Mencit. Journal of medicine and health. 1 (1): 1320. 
